Stephen Naumann*

Hillsdale College, Department of German, USA

https://orcid.org/0000-0002-0128-2623

\title{
Narratives Transcending Borders: Sabrina Janesch's Katzenberge as a German Response to Polish Migration Literature
}

Abstract: The establishment of the Oder-Neisse border between Poland and Germany, as well as the westward shift of Poland's eastern border resulted in migration for tens of millions in regions that had already been devastated by nearly a decade of forced evacuation, flight, war and genocide. In Poland, postwar authors such as Gdańsk's own Stefan Chwin and Paweł Huelle have begun to establish a fascinating narrative connecting now-Polish spaces with what are at least in part non-Polish pasts. In Germany, meanwhile, coming to terms with a past that includes the Vertreibung, or forced migration, of millions of Germans during the mid-1940s has been limited at best, in no small part on account of its implication of Germans in the role of victim. In her 2010 debut novel Katzenberge, however, German author Sabrina Janesch employs a Polish migration story to connect with her German readers. Her narrator, like Janesch herself, is a young (USA). In 2012 Stephen earned his Ph.D. in German Studies from Michigan State University with a dissertation exploring contested memory in the urban landscapes of Berlin and Poznań. In Europe he studied at both the Free University of Berlin and Adam Mickiewicz University in Poznań. He has published "Od pamięci spornej do wspólnej na przykładzie Dzielnicy Zamkowej w Poznaniu" (in Odkryj Dzielnicę Zamkową, Poznań, TRAKT, 2011). 
German who identifies with her Polish grandfather, whose death prompts her to trace the steps of his flight in 1945 from a Galician village to (then) German Silesia. This narrative, I argue, resonates with Janesch's German audience because the expulsion experience is one with which they can identify. That it centers on Polish migration, however, not only avoids the context of guilt associated with German migration during World War II, but also creates an opportunity to better comprehend their Polish neighbors as well as the geographical spaces that connect them. Instead of allowing border narratives to be limited by the very border they attempt to define, engaging with multiple narratives of a given border provide enhanced meanings in local and national contexts and beyond.

Key words: Polish-German border narratives, Paweł Huelle, Stefan Chwin, Günter Grass, Silesia, Galicia, Gdańsk.

\section{Introduction and historical context}

In this paper I show how Sabrina Janesch provides German readers with what Stefan Chwin and Paweł Huelle have given their Polish readership for decades now: namely, the ability to see migration from another perspective. Works by Chwin and Huelle have challenged their readers to consider German and Jewish experiences linked to transnational Polish spaces. By breaching national borders and stereotypes while utilizing multiple generations in her narrative, Janesch has tactfully broached the delicate topic of migration in postwar German literature. Before examining precisely how Janesch does this so successfully in her debut novel Katzenberge, I will provide useful historical context and theoretical background on postwar German migration literature, as well as contextualize the Polish works to which I refer.

In her introduction to a 2013 special issue of the journal German Politics and Society on German-Polish relations, Germanist Friederike Eigler summarizes some of the staggering migration numbers in Eastern Europe following 
the redrawing of German and Polish borders at the Yalta and Potsdam Conferences in 1945:

At the end of the war and in the immediate postwar period, approximately eight million ethnic Germans were expelled from territories that became part of Poland; furthermore, and this is little known in Germany, approximately one million Poles were forced to relocate from the Eastern territories that Poland lost to the Soviet Union (most of these Polish citizens were moved to the new Western territories of Poland) ${ }^{1}$.

This is the specific scene in 1945 Europe in which Katzenberge is set, following the migration narrative of a Polish couple who fled (then) Polish Galicia westward to what had been German Silesia. The fact that few Germans are even aware of the vast numbers of Poles who were displaced, as Eigler points out, is part of why Janesch's novel - written for a German audience has been so appropriate and effective. I will revisit this later in my analysis of the novel.

\section{The postmemorial and third-generation perspective}

Since 1990 Germany has seen a not insignificant amount of productive work on Vergangenheitsbewältigung - a term referring to Germans' struggling with or coming to terms with the past - with regard to World War II and the Holocaust, with Germans in the role of Täter or perpetrator. Yet since 1945, and even since reunification in 1990 when Vergangenheitsbewältigung began to pick up, the (forced) migration topic has remained difficult, in large part because of its implication, or perceived implication, of "Germans" in the role of Opfer or victim. The late Nobel laureate Günter Grass in fact chided the postwar (second) generation in his 2002 novel Im Krebsgang ${ }^{2}$ [English Crabwalk; Polish Idac rakiem $]^{3}$ for refusing to allow this migration narrative any space in the decades following the war. At the same time, however, the novel

1 F. Eigler, Moving Forward: New Perspectives on German-Polish Relations in Contemporary Europe, "German Politics and Society", Vol. 31, No. 4, New York: Berghahn Books, 2013, p. 2.

2 G. Grass, Im Krebsgang, Göttingen: Steidl Verlag, 2002.

3 G. Grass and K. Winston, Crabwalk, Orlando: Harcourt, 2004. 
also demonstrates how incendiary the narrative of German victimhood can be. As Germanist Kristin Kopp and comparatist Joanna Niżyńska put it, "the grandmother's unattended memory finds its outlet in her grandson, where it ultimately generates violence". This can be read as a broader form of "postmemory," a concept introduced by comparatist Marianne Hirsch in the context of Holocaust studies 5 . Hirsch defines postmemory as "the relationship that the 'generation after' bears to the personal, collective, and cultural trauma of those who came before - to experiences they 'remember' only by means of the stories, images, and behaviors among which they grew up"6.

Janesch's novel also presents the migration narrative from a postmemorial perspective and, more specifically, from a third-generation perspective $\mathrm{e}^{7,8}$. Eigler has described a "generational shift away from the first generation of witnesses, perpetrators, and victims and toward the second and third generations" In Katzenberge the narrator, Nele, repeatedly uses the phrase "Großvater sagte,..." [“Grandfather said,..."] to recount her Polish grandfather's experiences in his westward migration in 1945 from Galicia to Silesia. The thirdgeneration perspective is part of an important trend ${ }^{10}$ that has significantly impacted how we engage with past events both in literature and in public and

4 K. Kopp and J. Niżyńska, Germany, Poland and Postmemorial Relations: In Search of a Livable Past, New York: Palgrave Macmillan US, 2012, p. 10.

5 M. Hirsch, Family pictures: Maus, mourning, and post-memory, "Discourse", 15 (2), 1992 , pp. 3-29. JSTOR, www.jstor.org/stable/41389264.

6 Idem, Postmemory.net, https://www.postmemory.net/.

7 C. Winkler, A Third-generation Perspective on German-Polish Flight and Expulsion, "German Politics and Society”, Vol. 31, No. 4., New York: Berghahn Books, 2013, p. 85ff.

8 F. Eigler, Heimat, Space, Narrative: Toward a Transnational Approach to Flight and Expulsion, Rochester NY: Camden House, 2014, p. $151 \mathrm{ff}$.

9 Idem, Beyond the Victims Debate: Flight and Expulsion in Recent Novels by Authors from the Second and Third Generation (Christoph Hein, Reinhard Jirgl, Kathrin Schmidt, and Tanja Dückers), [in] Eds. L. Cohen-Pfister and S. Vees-Gulani, Generational Shifts in Contemporary German Culture, Rochester NY: Camden House, 2010, p. $77 \mathrm{ff}$.

10 In Kathrin Schmidt's Gunnar-Lennefsen Expedition and Tanja Dückers' Himmelskörper, Eigler identifies two other novels with transnational elements and third-generation authors that have begun "to open up traditional notions of Heimat and Germanness by tracing Polish and other national and ethnic affiliations in the process of rewriting 'German' family history." F. Eigler, Beyond the Victims Debate: Flight and Expulsion in Recent Novels by Authors from the Second and Third Generation (Christoph Hein, Reinhard Jirgl, Kathrin Schmidt, and Tanja Dückers), op. cit., p. 89. 
private discourse - whether that be connected to experience of war, trauma, guilt, loss of Heimat, migration, or the Holocaust.

German author Hans-Joachim Noack uses the verb riskieren (to risk) in referring to members of the third generation and their inquiry into the past, to which many are personally connected through family: "[V]or allem die Enkel scheinen nun einen unverstellten Blick jenseits von Schuld und Selbstkasteiung zu riskieren. Sie wollen das Unabänderliche nicht infrage stellen, sondern wissen, was war." ["It is the grandchildren in particular who seem willing to risk an undisguised glance beyond the guilt and self-mortification. They wish not to question that which is unchangeable, but simply to know what happened." ${ }^{11}$ Similarly, German journalist Annette Großbongardt points out, "Flucht und Vertreibung, die deutsche Vergangenheit im Osten... ist ausgerechnet bei den Jüngeren wieder attraktiv." ["Flight and expulsion, the German past in the East... is once again attractive to the younger generation of all people." ${ }^{12}$ In the German context, the third generation is able to pursue this narrative, since it does not carry the trauma (or perhaps contextual guilt) of the first generation's experience, and because it can operate with more temporal and emotional distance than the second generation, over which loomed the long shadow of the crimes for which their parents' generation was responsible. The grandchildren often simply want to know what happened, or "Was da geschah," as Noack puts it ${ }^{13}$.

\section{A German response to a Polish approach}

The aforementioned Grass novel Im Krebsgang recounts the 1945 sinking of the refugee ship Wilhelm Gustloff and is marked by conflict between the second and third generations, who share the narrative (making it, in part, another third-generation novel). If one reads Grass' novel as a warning of what

11 H-J. Noack, In Die Flucht: Über die Vertreibung der Deutschen aus dem Osten, Eds. S. Aust and S. Burgdorff, Bonn: Bundeszentrale für politische Bildung, 2005, p. 20. Translation is the author's.

12 A. Großbongardt, Neue Schlüssel zur Geschichte: Die Enkelgeneration der Vertriebenen sieht die Vergangenheit unverkrampfter, [in] Eds. A. Großbongardt, U. Klußmann and N. F. Pötzl, Die Deutschen im Osten Europas: Eroberer, Siedler, Vertriebene, Bonn: Bundeszentrale für politische Bildung, 2011, p. 18. Translation is the author's.

13 H-J. Noack, op. cit., p. 16. 
can happen when the discourse of traumatic experience (in this case, of German migrants) is suppressed, Sabrina Janesch's 2010 debut novel Katzenberge can be seen as an answer to Grass' warning, a unique and vital contribution to a broader public discourse of World War II migration - which one might say Grass' novel calls for.

But I would also like to propose Janesch's novel as a much-needed German response to an approach to migration in Polish literature, one that has been largely rooted in Grass' hometown of Gdańsk in the Baltic region of Pomerania, to the north of Lower Silesia, where Janesch's Katzenberge is set. Stefan Chwin (1949) and Paweł Huelle (1957) were both born after the Second World War in Polish Gdańsk, and both authors took a deep interest in the German and Jewish pasts of their city and its spaces. This is perhaps most evident in their choice of narrators, as the following three examples demonstrate.

Huelle's 1987 debut novel Weiser Dawidek ${ }^{14}$ [English Who Was David Weiser? ${ }^{15}$ recounts the mysterious disappearance of the eponymous character, a Jewish boy in 1950s Gdańsk. The narrator, Pawel, now in his 40s, recalls that summer he and his friends spent with Dawid, the episode of the latter's disappearance, and their subsequent interrogation by the authorities. The group spent its time playing in the ruins outside the city, and found weapons, helmets, and other items left by the Germans. Dawid organized magnificent colorful explosions in the chimneys of the old gasworks, and it was during one of these planned explosions that he disappeared. Pawel is haunted by Dawid's disappearance and is left asking himself - some 30 years later - whether he ever really existed at all. Dawid's character provides a chilling but effective metaphor for the post-1945 Jewish void in Poland, when the vast majority of some 3.5 million Polish Jews - what had constituted more than $10 \%$ of the pre-World War II population of Poland - were gone. Not only with his first name does the narrator Paweł resemble the author, but also by the fact that both were born after the war. Narrator Pawel's genuine curiosity about the Jewish and German pasts of his hometown represents, however, not only the curiosity of the author, but of the entire post-war generation of Polish Gdańsk. A similar narrator is

14 P. Huelle, Weiser Dawidek, Gdańsk: Wydawnictwo Morskie, 1987.

15 The book was translated into English by Michael Kandel and published in 1992. P. Huelle and M. Kandel, Who Was David Weiser?, Orlando: Harcourt Brace Jovanovich, 1992. 
the Polish child in Huelle's short story "Stół"16 [English "The Table"] ${ }^{17}$, whose parents are given a table from a German man, Mr. Polaske, who leaves Gdańsk after World War II. While his parents constantly argue about the table, the Germans, and the Soviets, their son is fascinated by Mr. Polaske, and in particular by a picture of him with pre-war Danzig in the background.

Stefan Chwin's 1995 novel Hanemann ${ }^{18}$ [English Death in Danzig; German Tod in Danzig $]^{19}$ centers on a German anatomist who resolves in spring of 1945 to remain in Gdańsk as so many Germans are leaving and Poles arriving on account of the shifted border. He shares his house with a Polish family from further east, and with a Ukrainian woman who finds work with the family, before eventually leaving after a few years because of pressure imposed by the Polish communist authorities. It is once again the Polish boy, fascinated by the details of Hanemann, who gathers every detail he can - from his own memories and those of the neighbors - to piece together the story of a man who represented his city from an enigmatic bygone era.

Historian Peter Oliver Loew, an authoritative voice on the history of Gdańsk/Danzig, demonstrates the influence Grass' (first-generation) work had on the postwar (second) generation of Polish novelists in Gdańsk once they were translated into Polish in the 1980s. Authors such as Chwin and Huelle began to investigate the German as well as Jewish pasts of the urban spaces and neighborhoods that they - as did Grass - call home ${ }^{20}$. Janesch, who represents the third-generation, has in turn been influenced by Grass as well as by Polish authors such as Chwin and Huelle ${ }^{21}$. Her first two novels Katzenberge and Ambra, like Grass and Huelle in particular, also employ elements of magic realism

16 P. Huelle, Stót, [in] idem, Opowiadania na czas przeprowadzki, London: Puls, 1991, pp. 7-23.

17 "Stół" was translated by Michael Kandel as "The Table" in 1991. P. Huelle and M. Kandel, The Table, [in] Moving House: Stories, New York: Harcourt Brace, (1991) 1995, pp. 3-35.

18 S. Chwin, Hanemann, Gdańsk: Wydawnictwo Tytuł, (1995) 2008.

19 S. Chwin and P. Boehm, Death in Danzig, Orlando: Harcourt, 2005.

20 Loew's essay was published in 2012 at the end of a special "Presse-Exemplar" (press edition) of Sabrina Janesch's second novel, Ambra. P.O. Loew, Danzig - Erinnerungsort Europas und Schauplatz großer Literatur [in] Ambra, Presse-Exemplar (Press edition), by Sabrina Janesch, Berlin 2012, Aufbau Verlag, pp. 377-378. http://www.sabrinajanesch.de/wp-content/uploads/2009/12/ Loew_Danzig.pdf.

21 Idem. 
in appealing to mythical or imaginary spaces. Loew argues that in literature since 1945, Gdańsk/Danzig has functioned as a European space rather than a Polish or German one, and Eigler makes the same case for Silesia and Galicia in Katzenberge: "[Janesch's novel] explore[s] alternative kinds of attachment to specific geographical places in contemporary Europe that can no longer be conceptualized in national parameters" 22 .

\section{Reading spaces as local/regional rather than national}

As mentioned above, Janesch's novel Katzenberge is told from the perspective of a third-generation protagonist. The narrator, Nele, like the author Janesch herself, is a young German woman from Berlin whose mother is Polish. Nele spends her summers with family in Polish Silesia, and particularly identifies with her Polish grandfather, whose death early in the novel prompts her to trace the steps of his flight in 1945 from a Galician village to (then) German Silesia. I argue that the work resonates with German readers because of their familiarity with and perhaps need for literature that addresses the important shared experience of expulsion and migration without being categorized as kitsch or creating a sense of guilt for engaging the topic in the first place. Secondly, the migration story told in Katzenberge is not one of German expellees leaving Silesia for the Germany inside the new post-1945 borders. Instead, the protagonist is a Polish man, Janeczko, fleeing west with his family and fellow villagers from Galician farms to far-away Silesia. The German protagonist, Nele, is Janeczko's granddaughter. She travels not westward, but eastward - first from Berlin to her grandfather's funeral, and then from Silesia to eastern Poland and finally Galicia to explore her grandfather's former home - a Heimat region "lost" to many Poles in 1945 just as Silesia was to so many Germans.

Janesch, therefore, is not writing about Germany and Poland per se, but about smaller local regions, namely Silesia and Galicia. Eigler writes that the novel "reference $[\mathrm{s}]$ the histories and memories of the "real" geographies of Silesian and Polish-Ukrainian border regions"23. Part of what allows Janesch's

22 F. Eigler, Heimat, Space, Narrative: Toward a Transnational Approach to Flight and Expulsion, op. cit., p. 179.

23 Ibid. 
novel to resonate is that in terms of place, she deals not with the national regions of Germany and Poland, but with two regions whose very names today invoke their respective multicultural pasts.

Germany and Poland share this topography of the Silesian space - a region that was displaced by the border shift - and therefore the two nations likewise share history and memory associated with that physical space and the inhabitants - past, present, and future - of that space. Success and progress in working through this shared history and memory, argues Eigler, is more attainable when approached from a transnational perspective ${ }^{24}$. Kopp and Niżyńska conclude that it is the combination of the local with the global - avoiding the rigidity and baggage of the national - that can prove advantageous and productive in these endeavors ${ }^{25}$. Indeed, to conceive of a space only in national paradigms is to invite weighty associations that are not easily forgotten - even generations after war and conflict. Examining a space from a local or regional perspective can more readily incorporate multiple perspectives.

Besides reaching across current and former national borders, the spaces affected by border shifts also reach across generations. Eigler uses the term "postmemorial spaces"26, that is, spaces that are both real to the first generation, marked by lived experience, and "imaginary" to the third generation that of the narrator - "carrying within them the postmemories of earlier times and other inhabitants" 27 .

Katzenberge is the story of the successful journey of a third-generation protagonist. Nele risks her present understanding of her grandfather, his past, and her own identity - all with which she is at peace - to engage an unknown past and present place to which her grandfather is connected: Galicia. She proves that this can be a positive experience that can break down mental barriers - between generations; between Germans and Poles; between Poles and Ukrainians; and between western Poles and eastern Poles.

24 Ibid., pp. 177-179.

25 K. Kopp and J. Niżyńska, op. cit., p. 21.

26 F. Eigler, Heimat, Space, Narrative: Toward a Transnational Approach to Flight and Expulsion, op. cit., p. 179.

27 Ibid., p. 176. 
Early in the novel, while trying to convince herself not to travel to Galicia, Nele observes: "Man brauche keine drei Sekunden, um im Internet festzustellen, wo Nele Leibert herkommt. Aus Berlin. Basta." ["It takes just three seconds on the Internet to find out where Nele Leibert is from. Berlin. Basta."] ${ }^{28}$ The novel demonstrates through Nele's subsequent travels, however, that one's heritage and identity are not as simple as belonging to one of the large, "national" categories that Europeans have created and to which so many have struggled to adhere.

After the funeral, it would have been easiest for Nele simply to return to her job, her friends and her boyfriend Carsten in Berlin. About the small Polish village Nele even explains: "Man verlässt Bagno schneller, als man es erreicht" ["One leaves [the village of] Bagno more quickly than one reaches it." ${ }^{29}$ Nele's mother proposes a trip to the Galician village - now in Ukraine where her grandfather lived before being forced out with other Poles in 1945. Nele is skeptical of the trip at first. She asks her mother, "Warum sollte man nach Galizien reisen, wenn alles, was Großvater betrifft, hier in Schlesien ist?" ["Why should I travel to Galicia, if everything regarding Grandfather is here in Silesia?"] ${ }^{30}$ Later, after having agreed to make the trip, Nele uses her work for a Berlin magazine as a cover - she would collect a few stories and photographs for an article - arguing with disinterest: "Spurensuche sei unseriös, etwas für Amerikaner und Melancholiker." ["Tracing one's roots is unambitious, something for Americans and melancholics." $]^{31,32}$

Her mother's answer convinces her otherwise, however: "Eben nicht alles, was deinen Großvater betrifft, ist hier in Schlesien. Hier in Schlesien, Töchterchen, ist höchstens die Hälfte." ["Not everything regarding your

28 S. Janesch, Katzenberge, Berlin: Aufbau Taschenbuch Verlag, (2010) 2012a, p. 42. Translation is the author's.

29 Ibid., p. 48. Translation is the author's.

30 Ibid., p. 42. Translation is the author's.

31 Ibid., p. 96. Translation is the author's.

32 Nele distances herself from those Germans who come back to Poland for what Karl Schlögel has called "Heimwehtourismus" [homesickness tourism], a phenomenon seen all over Europe because of shifted borders in the twentieth century (Schlögel, Die Mitte liegt ostwärts, München: Carl Hanser Verlag, 2002, p. 246). As one example, Nele is embarrassed riding with her father in his BMW bearing a German license plate as they passed some of the houses in the village (Janesch 2012a, p. 94). 
grandfather is here in Silesia. Here in Silesia, sweetheart, is barely the half of it." $]^{33}$

That Nele has much in common with her grandfather is stressed in the first half of the novel by the weaving together of two travel narratives that mirror one another: the grandfather's migration journey to Silesia in 1945 and Nele's trip to her grandfather's funeral in Silesia in the present. The two also share a great deal of sentiment for one another, and there are memories, conversations and shared experiences to which Nele repeatedly alludes from the summers she regularly spent with her grandfather and extended family in Silesia.

Yet there are also things the two do not share. Since Nele can move relatively effortlessly between Germany and Poland, speaks both languages, and identifies with family and friends in both cultures, she does not share her grandfather's experience of being a complete outsider. While certainly aware of tensions based on Poles' and Germans' shared past of the spaces in Silesia, Nele has access to both, whereas her grandfather led a group of villagers to a far-away place about which they knew nothing ${ }^{34}$. Nele recalls a question her grandfather asked while showing her a map of the area in what is now Ukraine where he came from: "Kannst du dir vorstellen, wie es sich anfühlt, wenn alles fremd ist?" ["Can you imagine what it feels like when everything is foreign?'] Nele answers no, asking her grandfather how it feels. This time his response was silence ${ }^{35}$.

Thus, Nele is the perfect character to be able to take her German readers interested in migration along on her continued journey in the opposite direction: to her grandfather's native Galicia. She is bright, educated, and well-traveled. She is also the only person in her Polish family (among her aunts, uncles and cousins) who is able to move so effortlessly between two national "spaces" and "cultures" (German and Polish). This experience aids her in her journey. Yet Nele is also somewhat stubborn about certain things, and she knows absolutely nothing about the country to the East to which she is traveling - a place to which she and her family are connected, and a place to which they often refer with disinterest and a stereotype-laden dismissiveness.

33 Ibid., p. 42. Translation is the author's.

34 When they first arrived in Silesia, the men stared at the high ceiling of the train station in Wrocław/Breslau, having never seen a building of that size before (Janesch 2012a, p. 24).

35 Ibid., p. 95. Translation is the author's. 
At the end of the novel, Nele returns from Galicia with her grandmother's handkerchief tied together and filled with some of the Galician earth from her grandparents' former village. She awakes before dawn and sets out on foot for the cemetery in Silesia where they are buried, walking through a mysterious but protective cover of fog. When she arrives, she opens her jacket to find that the handkerchief has come undone and nearly all of the dirt has fallen somewhere along the way as she walked between Morzęcin Mały and Bagno, where her grandparents were buried ${ }^{36}$. What little dirt remained was spread inside her jacket or caught in the fibers of her sweater. Brushing off what she could into a hole she had dug between her grandparents' gravestones, Nele asks herself, frustrated, "Wie viele Kilometer hatte ich zurückgelegt, und alles nur wegen dieses einen Ziels?" ["How many kilometers had I logged, and everything only because of this one goal?"] ${ }^{36}$ However, both Nele and the reader, I would argue, have accomplished much more than just the symbolic "goal" to which Nele alludes. Nele has gained a richer understanding of both her grandfather and herself, as well as the journey they share and the spaces that now connect them. Janesch's German readers benefit from a meaningful migration story with which they can well identify. The fact that it centers on Polish migration not only avoids the context of guilt associated with German migration during World War II, but also creates an opportunity to better comprehend their Polish neighbors as well as the geographical spaces and mutual experiences that connect them.

\section{Conclusion}

Polish historian Robert Traba, founder of Fundacja "Borussia"38, said of the third generation: "[D]ie neue Generation sucht neue Schlüssel, um die Geschichte erfahrbar zu machen" ["The new generation is looking for new keys, in order to make history tangible"] ${ }^{39}$. Janesch's migration narrative in the novel Katzenberge has provided one such key, not merely because of the generation

36 Ibid., p. 269.

37 Ibid. Translation is the author's.

38 Fundacja "Borussia" is a nongovernmental organization, founded in 2006, that promotes transnational research and dialogue concerning the Warmia and Masuria regions of Poland. "Borussia" is the Latin designation for Prussia.

39 Quoted in A. Großbongardt, op. cit., p. 18. Translation is the author's. 
she represents, but also on account of the story she tells. The novel was praised in reviews from a wide range of German publications from Der Spiegel to Frankfurter Allgemeine Zeitung, while Janesch was decorated with prestigious literary awards such as the Mara-Cassens-Preis, the Anna-Seghers-Preis and the Nicolas-Born-Förderpreis ${ }^{40}$.

Janesch's narrative, I argue, has resonated with her German audience because the story is one with which they can identify. The author not only takes a step towards altering the paradigm, but also provides her German readership with an opportunity to reflect upon a Polish experience that, though it in many ways parallels the experience of German refugees at the end of the war, is far less familiar to most Germans. German journalist Hans-Joachim Noack describes certain Polish authors who see in those German refugees what Noack refers to as Schicksalsgefährten or companions in fate or suffering ${ }^{41}$. Though it is perhaps just beneath the surface of the narrative, calling readers' attention to the similarities of this shared experience is potentially the greatest feat of Janesch's novel, and one that - as was the case with Grass' Im Krebsgang a decade earlier - should lead to increased dialogue about migration among the current generation and those to follow.

\section{References}

Aust, S., \& Burgdorff, S. (2005). Die Flucht: Über die Vertreibung der Deutschen aus dem Osten. Bonn: Bundeszentrale für politische Bildung.

Chwin, S., \& Boehm, P. (2005). Death in Danzig. Orlando: Harcourt.

Chwin, S. (2008). Hanemann. Gdańsk: Wydawnictwo Tytuł.

Eigler, F. (2010). Beyond the Victims Debate: Flight and Expulsion in Recent Novels by Authors from the Second and Third Generation (Christoph Hein, Reinhard Jirgl,

40 Cf. Polnische Sippensaga, "Der Spiegel”, 14 March 2011, https://www.spiegel.de/spiegel/ print/d-77435301.html; C. Schärf, Im Reich der Oberhexe Baba Jaga, "Frankfurter Allegmeine Zeitung", 29 July 2011, https://www.faz.net/-gr4-6lara.

41 H-J. Noack, op. cit., p. 20. 
Kathrin Schmidt and Tanja Dückers). In L. Cohen-Pfister \& S. Vees-Gulani (Eds.), Generational Shifts in Contemporary German Culture (pp. 77-94). Rochester NY: Camden House.

Eigler, F. (2014). Heimat, Space, Narrative: Toward a Transnational Approach to Flight and Expulsion. Rochester NY: Camden House.

Eigler, F. (2013). Moving Forward: New Perspectives on German-Polish Relations in Contemporary Europe. German Politics and Society, 31(4), 1-15.

Gieba, K. (2015). Literatura dotycząca powojennych przesiedleń na tzw. Ziemie Odzyskane - przegląd koncepcji badawczych i próba defenicji. Zagadnienie Rodzajów Literackich, LIX z. 2, 77-89.

Grass, G., \& Winston, K. (2004). Crabwalk. Orlando: Harcourt.

Grass, G. (2002). Im Krebsgang. Göttingen: Steidl Verlag.

Grass, G. (2007). Unkenrufe. Göttingen: Steidl Verlag.

Großbongardt, A., Klußmann, U., \& Pötzl, N. (2011). Die Deutschen im Osten Europas: Eroberer, Siedler, Vertriebene. Bonn: Bundeszentrale für politische Bildung. Großbongardt, A. (2011). Neue Schlüssel zur Geschichte: Die Enkelgeneration der Vertriebenen sieht die Vergangenheit unverkrampfter. In A. Großbongardt, U. Klußmann, \& N. F. Pötzl (Eds.), Die Deutschen im Osten Europas: Eroberer, Siedler, Vertriebene (pp. 17-28). Bonn: Bundeszentrale für politische Bildung.

Hirsch, M. (1992). Family pictures: Maus, mourning, and post-memory. Discourse, 15 (2), 3-29.

Hirsch, M. Postmemory.net. https://www.postmemory.net/ Huelle, P. (1991). Stół. In Opowiadania na czas przeprowadzki (pp. 7-23). London: Puls.

Huelle, P. (1987). Weiser Dawidek. Gdańsk: Wydawnictwo Morskie.

Huelle, P., \& Kandel, M. (1995). The Table. In Moving House: Stories (pp. 3-35). New York: Harcourt Brace.

Huelle, P., \& Kandel, M. (1992). Who Was David Weiser?, Orlando: Harcourt Brace Jovanovich.

Janesch, S. (2012a). Katzenberge. Berlin: Aufbau Taschenbuch Verlag. Janesch, S. (2012b). Ambra. Presse-Exemplar (Press edition). Berlin: Aufbau Verlag. Kopp, K. \& Niżyńska, J. (2012). Between Entitlement and Reconciliation: Germany and Poland's Postmemory after 1989. In K. Kopp \& J. Niżyńska (Eds.), Germany, Poland and Postmemorial Relations: In Search of a Livable Past (pp. 1-24). New York: Palgrave Macmillan US. 
Kopp, K. \& Niżyńska, J. (2012). Germany, Poland and Postmemorial Relations: In Search of a Livable Past. New York: Palgrave Macmillan US.

Loew, P. O. (2012). Danzig - Erinnerungsort Europas und Schauplatz großer Literatur. In S. Janesch, Ambra (pp. 375-389), Presse-Exemplar (Press edition). Berlin: Aufbau Verlag. http://www.sabrinajanesch.de/wp-content/uploads/2009/12/ Loew_Danzig.pdf

Noack, H-J. (2005). In S. Aust \& S. Burgdorff (Eds.), Die Flucht: Über die Vertreibung der Deutschen aus dem Osten (pp. 15-20). Bonn: Bundeszentrale für politische Bildung.

Polnische Sippensaga (2011, March 14). Der Spiegel. https://www.spiegel.de/spiegel/print/d-77435301.html

Schärf, C. (2011, July 29). Im Reich der Oberhexe Baba Jaga. Frankfurter Allegmeine Zeitung. https://www.faz.net/-gr4-6lara

Schlögel, K. (2002). Die Mitte liegt ostwärts. München: Carl Hanser Verlag.

Schlögel, K. (2013). Grenzland Europa: Unterwegs auf einem neuen Kontinent. München: Carl Hanser Verlag.

Winkler, C. (2013). A Third-generation Perspective on German-Polish Flight and Expulsion. German Politics and Society, 31(4), 85-101. 